Politics and the Film in Tamilnadu: The Stars and the DMK

Author(s): Robert L. Hardgrave, Jr.

Source: Asian Survey, Vol. 13, No. 3 (Mar., 1973), pp. 288-305

Published by: University of California Press

Stable URL: http://www.jstor.org/stable/2643038

Accessed: 05-08-2015 17:57 UTC

Your use of the JSTOR archive indicates your acceptance of the Terms \& Conditions of Use, available at http://www.jstor.org/page/ info/about/policies/terms.jsp

JSTOR is a not-for-profit service that helps scholars, researchers, and students discover, use, and build upon a wide range of content in a trusted digital archive. We use information technology and tools to increase productivity and facilitate new forms of scholarship. For more information about JSTOR, please contact support@jstor.org. 


\section{IN TAMILNADU: THE}

STARS AND THE DMK

\section{/ Robert L. Hardgrave, Jr.*}

\section{$n$}

he Dravida Munnetra Kazhagam (DMK), the ruling party of Tamilnadu State in India, has split in climax to persistent rumors of intraparty discord and impending schism. M. G. Ramachandran, DMK party treasurer and popular Tamil film star, was stripped of his party offices and suspended from membership in the party to which he had so long brought support from his devoted fans.

The crisis culminated a long feud between M.G.R. and Chief Minister M. Karunanidhi. In the early months of 1972 , as Karunanidhi, in demands for regional autonomy, began to tout himself as the "Mujib of Tamilnadu," M.G.R. protested Karunanidhi's "dictatorial methods" and called for a boycott of the party's General Council in protest against one man rule. His criticism of Karunanidhi and the party leadership mounted with his demand for a party probe into rampant corruption. M.G.R. called for a disclosure of all assets of ministers, legislators, and party officials-and assets of their close relatives. Party careerists were alarmed: M.G.R.'s public utterances violated party discipline and, in discrediting party and Government, created confusion in the public mind. A memorandum, submitted by 26 members of the DMK Central Executive, called for disciplinary action against M.G.R. His suspension, sustained by the General Council, soon followed.

M.G.R. appealed to party members to remain loyal to the ideals of C. N. Annadurai, founder of the DMK and Chief Minister until his death in 1969. To continue his policies, M.G.R. announced the formation of a rival party, the Anna DMK, to challenge the legitimacy of Karunanidhi's leadership. M.G.R. "fan clubs," long adjuncts of the DMK, now became branches of the new party. Many regular DMK branches throughout Tamilnadu also switched allegiance to M.G.R. The star's fans paraded in the streets. In Madurai, they pulled down DMK flags and stoned Government buses; in Vellore, they brought off a total hartal; in Madras, rickshaw men went on strike in protest against the party's suspension of their idol and protector.

*I wish to acknowledge the invaluable contribution of my research assistant in this study, Sriram Athri, whose initiative and sensitivity to the research problems were major ingredients of the project's successful completion. The study was made under a Ford Foundation Research Grant. 
On the other side, M.G.R. posters were defaced and torn, and theaters showing his films were attacked, as were M.G.R. fan clubs. Perhaps fearing reprisal, the scheduled release of a film starring M. K. Muthu, Karunanidhi's son, was postponed. Muthu, who had only begun to act in films, had already incurred M.G.R.'s wrath by an alleged attempt to convert M.G.R. fan clubs into Muthu Associations. The aging actor, no doubt, did not take this too kindly.

The role of film in the politics of Tamilnadu has been significant, and the influence of the "stars" on Tamil politics has made political astrologers of those who would seek to understand it. During the course of the 1967 election campaign, the New York Times carried an article describing film star involvement in the politics of Tamilnadu as having "a touch of California." Film has become increasingly pervasive in almost all aspects of Tamil society and perhaps most prominently in political life. Although Bombay is usually considered the capital of the Indian film world, it is within South India that film has made its greatest impact. The film industry in the South, centered in the city of Madras, is the largest in India-in the number of studios, capital investment, gross income, and in the number of people engaged in the industry. Since 1931, when the "talkie" was first introduced in the South, some 1500 films have been made in Tamil. Half of India's six thousand cinemas are located in the southern region-and half of these are in the state of Tamilnadu. Virtually no village in Tamilnadu is so isolated to be beyond the reach of film, and even the poorest laborer can afford the few pice to see the latest production.

Early Tamil films were largely "mythologicals," but with the first "social" films in 1936 came an infusion of politics. The Congress sought to use the motion picture for nationalist propaganda. One Tamil social, for example, dealt with prohibition, part of the Congress program, and it included a popular song about the importance of the spinning wheel, strongly advocated by Gandhi. Sometimes a portrait of Gandhi would appear inconspicuously in the background in hope that it might slip past the British censors. The Congress also used film stars to attract crowds. K. B. Sundarambal, an actress famous for devotional songs, regularly appeared on the platform of the Tamil Congress leader, S. Satyamurthi. ${ }^{1}$

While the Congress in Tamilnadu made early use of the film, most Congressmen looked on the medium with contempt and shared C. Rajagopalachari's view of the cinema as a source of moral corruption. It was only the party of Tamil nationalism, the DMK, that took film seriously as a vehicle of political mobilization. With Lenin, the leaders of the DMK regarded film as the most important art form because it was the most popular. Congressmen never realized the power of film, says Kannadhasan, song writer

\footnotetext{
${ }^{1}$ Interview, S. Punju, Tamil film director, Madras, January 1970.
} 
for the Tamil screen and one of the founders of the DMK. "They decried the cinema. We used it."2

The DMK's involvement in the Tamil film industry is rooted in the Dravidian Movement for non-Brahmin uplift in South India. ${ }^{3}$ Writers and actors who had matured in the touring dramatic companies associated with E. V. Ramaswamy Naicker's Self-Respect Movement came to dominate the Tamil screen. From the "guerilla theater" of Tamil nationalism, they brought anti-northern, anti-Brahmin themes. Their Tamil was purged of Sanskritic elements in assertion of Dravidian self-respect; the golden age of the Tamil kingdoms was resurrected on celluloid; Brahmins were depicted as sinister or foolish.

In organizing the Dravida Kazhagam (or Dravidian Federation) in 1944, E. V. Ramaswamy sought to extend his movement for social reform and uplift to the demand for a separate and independent state of Dravidasthan. The DK, in spite of its appeal to the masses, was a quasi-military organization and basically elitist in character. Seeking democratic party organization and electoral involvement in the newly independent India, a dissident faction broke with E.V.R. in 1949 and founded the Dravida Munnetra Kazhagam (Dravidian Progressive Federation). The leader of the new party was a young film writer, C. N. Annadurai. Among those joining him were M. Karunanidhi, another film writer, and a number of film stars, including K. R. Ramaswamy, S. S. Rajendran, and Shivaji Ganesan, who later left the DMK for Congress, to be replaced by M. G. Ramachandran. Their films introduced symbols and references to the DMK, and the party rode the rising popularity of cinema. Film ariists brought glamour and electoral support to the DMK, and actors graced the platforms of party rallies. Some stars, like M. G. Ramachandran and S. S. Rajendran, converted their popularity on the screen into successful bids for seats in the Legislative Assembly.

K. Kamaraj, former Chief Minister of Tamilnadu and then president of the All-India Congress Party, scoffed at the DMK's aspirations to power: "How can there be government by actors?" 4 In 1967, in a landslide victory, the DMK with Annadurai as Chief Minister took control of the State.

\footnotetext{
${ }^{2}$ Interview, Kannadhasan, Madras, January 1970. Kannadhasan left the DMK in 1962 to join E. V. K. Sampath's Tamil National Party and with Sampath in 1964, he joined Congress. In opposition to the DMK, Kannadhasan has been out of favor with DMK film stars like M. G. Ramachandran, but the popularity of his songs is so great that he is frequently signed for DMK films.

${ }^{3}$ See Robert L. Hardgrave, Jr., The Dravidian Movement (Bombay: Popular Prakashan, 1965) and Eugene Irschick, Politics and Social Conflict in South India: The Non-Brahmin Movement and Tamil Separatism 1916-1929 (Berkeley: University of California Press, 1969). For an examination of the DMK, see also Marguerite Ross Barnett, The Politics of Cultural Nationalism in South India (forthcoming); Mohan Ram, Hindi Against India (New Delhi: Rachna Prakashan, 1968); P. Spratt, DMK in Power (Bombay: Nachiketa, 1970); K. S. Ramanujam, The Big Change (Madras: Higginbothams, 1967), and K. S. Ramanujam, Challenge and Response (Madras: Sundara Prachuralayam, 1971).

${ }^{4}$ Erik Barnouw and S. Krishnaswamy, Indian Film, (New York: Columbia University Press, 1963), p. 175.
} 
Within the DMK leadership of the new Government were many associated in one way or another with the film industry or with earlier dramatic careers. Some had been no more than stagehands or ticket takers for the troupes of the Dravidian Movement two decades before; others had become film stars, producers, directors, or writers. The stars, like M.G.R., had mass appeal, but it was through film writers that the DMK had made its initial impact-through C. N. Annadurai, founder of the party and Chief Minister of Tamilnadu until his death in 1969, and M. Karunanidhi, who succeeded "Anna" as Chief Minister and party leader.

As a young lieutenant of the Dravida Kazhagam, Annadurai had written a number of dramas as vehicles for social reform and non-Brahmin selfrespect. After the DMK was founded, Annadurai, E. V. K. Sampath, and K. R. Ramaswamy, then Tamilnadu's most popular actor and film star, staged dramas in benefit performances for the party. The DMK head office at Royapuram in Madras City was purchased with these funds. ${ }^{5}$ From plays, Annadurai entered the film world. He wrote six screenplays_-"with a view," he said, "to educating the people of Tamilnad. All my stories and screenplays have, therefore, been on themes of social purpose." His first film, Nalla Thambi ("Good Brother," 1948), featuring the popular actorcomedian N. S. Krishnan, advocated prohibition, cooperative farming, and zamindari abolition. Velaikari ("Servant Maid," 1949) "made it clear that the greed and avarice of the rich did not pay in the long run." Here Annadurai explained "some of the elementary principles of socialism and stressed that we should depend upon our own labor for our progress and well being and not some unknown factor."6

Velaikari, with its attack on religious dogma, was regarded as a revolutionary film. The story itself, however, raises some serious questions. A landlord was pressuring a debtor for money, and the man, in shame, commits suicide. His son, played by K. R. Ramaswamy, vows to punish the landlord and devises a plan by which, through impersonation, he marries the landlord's daughter. By design, he then mistreats the girl and develops a reputation for drunkenness and gambling so as to bring disgrace upon his father-in-law. He then encourages the father to forbid an intercaste marriage between his son and a servant girl and, to bring the family into final wreckage, succeeds in having the distraught son thrown out of the house. With further complications, our "hero" announces his purpose. Overcome with emotion, the father sees the error of his own ways. He blesses the marriage of his daughter to the revealed son of the debtor, and, in final retribution, approves the marriage of his son to the servant maid. The old man never really emerges as a villain but the hero certainly comes

${ }^{8}$ Interview with K. R. Ramaswamy, Madras, January 1970, and with E. V. K. Sampath, Madras, February 1970. Sampath was the nephew of E. V. Ramaswamy and the No. 2 man in the DMK until he bolted the party in 1962 to found the Tamil National Party. He subsequently joined the Congress.

${ }^{6}$ Interview with C. N. Annadurai in Filmfare, May 10, 1968, p. 45. 
out as a dastardly character. If personal vendetta designed to destroy a man's family is social reform, it is a curious moral indeed.

The film, no doubt, had shocking aspects. After a scene in which the landlord offers puja before Kali, showing the hypocrisy of religion, Ramaswamy - who had spent all his money in offerings after his father's sui-cide-upturns the offerings before the goddess. He shakes his fist at the deity and in a long monologue says, "Just as the rich man lives on the sweat of the poor, you do likewise."

Soon after Velaikari, M. Karunanidhi's Parasakthi (1952) stunned the Tamil audience. The film, a screen version of an earlier play, was initially banned, but with its release, it became an enormous box office success. ${ }^{7}$ Karunanidhi, who wrote the screenplay, had been an early associate of the DK and had written on the themes of Dravidian self-respect. As a founding member of the DMK, he lent his talent to the new movement. "My intention was to introduce the ideas and policies of social reform and justice in the films and bring up the status of the Tamil language as they were called for in DMK policies." Karunanidhi emphasizes the view of the party on the role of film. "We say that art should be for propaganda-for the people and for society."

Parasakthi, according to its director, S. Punju, was designed to "create havoc. Of course, it did. We were challenging the social law itself, the basic Constitution itself."9 One of the most dramatic scenes of the film involved the attempted seduction of a young girl by a priest of the temple. Before the idol itself, the priest molests the girl. The hero (played by Shivaji Ganesan) saves her and then expounds upon the social philosophy of the DMK. The scene of the temple seduction was drawn from fact-a case that went all the way to the Madras High Court and created a popular sensation. We don't object to the temple, Punju says of the DMK stance on religion, but to the evil-minded people who use it. The DMK believes in one god, but opposes the bribery of god through puja. ${ }^{10}$

The entry of the Dravidian Movement into the film industry brought a new era in the Tamil screen. In the years before 1949-1950, film dialogue had been awkward-really a Brahminical slang. Annadurai and Karu-

\footnotetext{
${ }^{7}$ S. Punju, director of Parasakthi, had wanted K. R. Ramaswamy, who was then getting about Rs. 40,000 per film, for the picture to ensure star attraction. Ramaswamy and Karunanidhi, however, were at odds within the party, and Ramaswamy refused to act in the film. Annadurai suggested that Shivaji Ganesan be cast as the hero. Although he had never acted in film, Shivaji had been popular in Anna's dramas. Punju signed Shivaji for Rs. 250 per month-quite a bargain compared to what K.R.R. would have commanded. S. S. Rajendran, a young actor associated with the Dravidian Movement, was also introduced in the film. Interview, S. Punju, Madras, January 1970.

${ }^{8}$ Interview with M. Karunanidhi, Chief Minister of Tamilnadu, Madras, February 1970.

${ }^{\circ}$ Interview, S. Punju, Madras, January 1970.

${ }^{10} \mathrm{Ibid}$. Ironically, for all of Parasakthi's anti-religious character, each day of production was begun with the propitious breaking of a coconut and the burning of camphor. Most of the people in the film industry go on sentiment, says Punju, and while he has no use for puja, "we are all business people, so we let them have it."
} 
nanidhi brought particular prominence to the spoken word, and in the early DMK films, dialogue was of a highly literary, "chaste" Tamil, almost like formal speeches. Indeed, DMK party speeches are heavily influenced by dramatic form. They are rich with alliteration and employ a euphonic stage style-filled, according to its critics, with sound and fury signifying nothing. These speeches, whether from the platform or the cinema screen, come as "a rain of words" (sorpozhivu) and have popularized a highly ornate form of spoken Tamil.11

Annadurai's film dialogues tended to be rather high-flown and lacked the more popular appeal of those by Karunanidhi, who in more than thirty films has sought to provide entertainment along with party propaganda. Through film, both Anna and Karunanidhi became "stars" in their own right. People wanted to see them at public meetings, to have darsham before them. Their films were vehicles for both social reform and party propaganda. Their themes were of widow-remarriage, untouchability, the selfrespect marriage (introduced by E.V.R. to eliminate the use of the Brahmin priest in the wedding ceremony), zamindari abolition, prohibition, and religious hypocrisy. "We wanted to bring revolution in the mind," says DMK director and Member of the Legislative Assembly, Rama Aranganal, "and to some extent we succeeded."12

The DMK films served an audience the party could never have reached by other means. The ideology of the DMK, explains Murasoli Maran, faces both the past and the future, and this is reflected in film. The Tamil past -its rich language and culture - are glorified in story and song. Rationalism and social reform are extolled in attacks on caste, religious dogma, social injustice, and economic exploitation. Maran underscores the fact that for the common man, the cinema is the only form of entertainment. "So far as our party is concerned, we have made use of it as a vehicle of our social reform policy. In every story, we mix amusement with instruction, and we explain our programs of social reform."13 Some of the early "revolutionary" films of the DMK were so heavy with social reform that they were box office failures. DMK producers, says Maran, are now more sensitive to the story element, to the entertainment value. "We select a good story and introduce our ideology wherever possible."14

The shift away from the more radical films-particularly those of an anti-religious character-was in part a product of official censorship. The early DMK films met little difficulty for all their controversial content. The party was little known and censors made no connection between film theme

\footnotetext{
${ }^{11}$ See Design, "Mass Media and the DMK," n.d., pp. 34-36.

${ }^{12}$ Interview, Rama Aranganal, Madras, December 1969. Rama Aranganal was associated with E.V.R. in the 1940s and was assistant editor of the DK newspaper, Viduthalai. In 1949, he became one of the founding members of the DMK and edited Annadurai's weekly Dravida Nadu. He entered film as a dialogue writer about 1950 and later became a producer. He has served as a Member of the Legislative Assembly since 1962.

${ }^{13}$ Interview, Murasoli Maran, Madras, December 1969.

${ }^{14}$ Ibid.
} 
and party ideology. By the mid-1950s, however, it was evident that the DMK was attempting to use the motion picture to advance its political position. Maran is convinced that film censorship was consciously used by the government to undercut the DMK. One technique, he says, was to censor and cut critical elements of a film so as to destroy the picture's coherence and thus ensure financial failure. In the period of greater conflict with the censors, the party turned again to drama. "Under the Dramatic Licensing Act," Maran relates, "we were required to give the script to the police. We would give them some ordinary script, then enact something else in the drama." This didn't always succeed, for three of Karunanidhi's plays were banned by the state Congress government. ${ }^{15}$

In producing films under close censorship, the DMK turned to subterfuge. The use of double meanings in dialogue became a DMK forte. They also created a character called "Anna"-the Tamil word for older brother and the popular name for Annadurai-who appeared in almost all the DMK films as a wise and sympathetic counsellor. In an historical film, for example, the dialogue might go, "Anna, you are going to rule one day," at which the audience would break into wild applause. The historical film was particularly useful for the party, for it provided both an opportunity to eulogize Tamil culture and the glory of the Tamil kingdoms and, at the same time, to subtly comment on current political affairs. Maran tells the story of one film, Kanchee Talaivar, about a Pallava king whose capital was the city of Kanchee (Kancheepuram). Not without coincidence, Annadurai was from Kanchee, and he was known as Kanchee Talaivar, "the leader of Kanchee." The censors demanded a change of title, but, after all, it did refer to a Pallava kingdom. The DMK got the title, but the censors so badly mangled the film that it was a financial failure. ${ }^{16}$

The shift from social reform as the dominant theme of the DMK films, whatever considerations for government censorship, was primarily political. As the party entered the electoral arena, it sought less obtrusive subject matter. In courting the electorate, the DMK could no longer afford the iconoclasm of the old Self-Respect Movement, with its blatant attack on the social and religious institutions of Hindu orthodoxy. "The DMK films are no longer revolutionary," says one disgruntled DMK Member of the Legislative Council. "We are now chasing votes, and our principles have been watered down."

Displacing content as the thrust of the DMK's use of the film media, the party now sought to emphasize star popularity as a vehicle for political mobilization. The DMK now hitched its political wagon to the stars of the silver screen. The movement's association with dramatic and film actors, however, was not wholly a new phenomenon. DMK actors had grown up

${ }^{15}$ Ibid.

${ }^{16}$ Ibid. 
in the Self-Respect Movement and the DK of E. V. Ramaswamy, and many were among the founding members of the DMK.

In 1949, with the founding of DMK, the actor K. R. Ramaswamy provided financial support for the struggling party. "Only with my earnings was the party founded," he says. ${ }^{17}$ He had met Annadurai through E. V. Ramaswamy, and it was his dramatic company which produced Anna's first play, Velaikari. When the play was later filmed, K. R. Ramaswamy was the star. At this time, Ramaswamy had reached the pinnacle of the Tamil film world. From his first film in 1944 (Poompavai, "Lady With Flowers," directed by S. Punju), K.R.R. rapidly became one of the most popular actors in South India. He could both sing and act-a critical combination before "playback" and when a film might easily have thirty songs or more. Indeed, he was known by the title, Nadippisai Pulavar, "the ActingSinging Poet." With the "playback" dubbed into the sound track, however, a popular singer could warble to the silent mime of the actor, and Ramaswamy began to lose out to rising young stars who had no need of singing talent. At about this time, in the early 1950s, personal problems brought his career into ruin. Later, in reward for his services to the party, Annadurai secured for K. R. Ramaswamy nomination as a Member of the Legislative Council, the upper house of the state government.

Although he was never a member of the DMK, N. S. Krishnan lent his enormous popularity to the party. Krishnan was the greatest comedian of the Tamil screen and, as the times required, a very fine singer. His appearances ensured a film's success. "Without him," says Maran, "there wouldn't be any picture."18 Krishnan was particularly famous for his roles as the Brahmin buffoon, which he would recreate to the delight of his audience at DMK rallies. During the 1940s, the film industry was dominated by Brahmin producers and by Brahminical themes. N. S. Krishnan was a notable exception. Influenced by E. V. Ramaswamy, Krishnan introduced in his comic scripts - which he wrote himself-the seeds of non-Brahminism which were later to become the driving force of the DMK. ${ }^{19}$ In the last public function before his death, Annadurai, on January 14, 1969, unveiled a statue of N. S. Krishnan, located at a busy Madras intersection. ${ }^{20}$

Although never sympathetic with the DMK, one actor closely associated with many of the DMK leaders when they were still devoted followers of E. V. Ramaswamy's DK was M. R. Radha. Radha, arch villain of the Tamil

\footnotetext{
${ }^{17}$ Interview, K. R. Ramaswamy, Madras, January 1970.

${ }^{18}$ Interview, Murasoli Maran, Madras, December 1969.

${ }^{10}$ Interview, V. P. Raman, Madras, January 1970.

${ }^{20}$ In the mid $1940 \mathrm{~s}, \mathrm{~N}$. S. Krishnan became involved in a notorious murder case. He was finally acquitted, but in order to raise money for his appeal, his friends decided to make a picture, Mad Man (1947). Punju, the director had been long involved in the Dravidian movement and had presided over a number of widow remarriages. This, Punju decided, was to be the theme of the movie (but, to be on the safe side, it was to be a virgin widow). It was this film which brought Annadurai into association with Punju, who later directed Anna's first film, Nalla Thambi ("Good Little Brother," 1949). Interview, S. Punju, Madras, January 1970.
} 
screen, and would-be assassin of M. G. Ramachandran, came into contact with E.V.R. during the early 1940s through his dramatic performances. Radha had one of the leading troupes in South India, the Social Reform Company, and he presented plays on anti-Brahmin and atheist themes. Almost all of the DK-DMK people were associated with Radha at one time or another during this period, and the young DK writers, Annadurai and Karunanidhi, both of whom were in the dramatic company, often acted in the plays. Annadurai is once reported to have said that he really cared only for the acting of M. R. Radha and Shivaji Ganesan. ${ }^{21}$

V. C. Ganesan ("Shivaji"), like so many actors of Tamilnadu, has been on the stage most of his life. ${ }^{22}$ From the age of six, Shivaji toured with various companies, including the famous troupe of M. R. Radha, playing both male and female roles. In 1949, Ganesan appeared in a play written by C. N. Annadurai, Chandra Mohan, which depicted the triumph of the Maratha hero Shivaji over the Brahmins. Annadurai himself played a villainous Brahmin priest. Ganesan played the role of Shivaji. Periyar E. V. Ramaswamy presided over the first performance and was so impressed that he bestowed the name "Shivaji" on the young actor.

In Tamilnadu, politics is a bedfellow of almost every film artist. For Shivaji, it is a subsidiary but clearly apparent facet of his public image. Shivaji had been politically weaned in the DK and was one of the founding members of the DMK. It was through the party that he got his start in film. At Annadurai's suggestion, Shivaji was offered the leading role in the film Parasakthi. The "powerful dialogues" and screenplay were by M. Karunanidhi. Released in 1952, the film was an immediate sensation, and Shivaji, at the age of 24, was launched on a stellar career. He made many contributions to the party coffers and served as a drawing card at political rallies, but Shivaji had never really been involved in party activities, and its demands pressed upon him. If the DMK had given him his initial boost in his film career, it also served to limit his horizons. A reputation of atheism, arising from his association with E.V.R. and the movement, did not set well with a fundamentally religious audience. Perhaps feeling that the opposition party was no longer an asset, Shivaji attacked the DMK as a "glamour" party which exploited the Tamil film industry. In 1955, in a flurry of publicity in connection with the release of a new picture, Shivaji went to Tirupathi temple. When he returned, he was publicly abused by

\footnotetext{
${ }^{21}$ Interview with E. V. K. Sampath, Madras, February 1970; with Thirumal, personal secretary to M. R. Radha, Madras, February, 1970; and with M. R. Radha-the interview conducted in February 1970 in the Madras Center Jail, where Radha was serving sentence for the attempted murder of M.G.R. Details of the assassination attempt are discussed in Hardgrave, "When Stars Displace Gods: The Folklore of Cinema in Tamilnadu," in Charles Leslie (ed.), Asian Films and Popular Culture (forthcoming).

${ }^{22}$ For a discussion of Shivaji and other stars of the Tamil screen in their broader relation to Tamil society, see Hardgrave, "When Stars Displace the Gods: The Folklore of Cinema in Tamilnadu," op. cit.
} 
DMK members, and his photographs and billboards were defaced with mud and dung.

In 1961, Shivaji warned, "Artists keep away from politics," but extended his support to the new Tamil Nationalist Party, a split from the DMK, ${ }^{23}$ and staged a benefit drama for the party's election fund. When the party dissolved and its leader, E. V. K. Sampath, joined Congress, Shivaji followed. Today he described himself as a "200 percent Congressman." ${ }^{24}$ His lithographic portraits are emblazoned against the Congress flag, and he proclaims Kamaraj as his leader. During the 1967 elections, Shivaji toured throughout Tamilnadu for the Congress. With no interest in running for office, however, Shivaji is only tangentially involved in Congress workalmost entirely in electoral campaigns. He keeps his politics away from art, and his films are generally free of political overtone.

Among the founding members of the DMK was another young actor, S. S. Rajendran, who, like Shivaji, had been introduced in Karunanidhi's Parasakthi. S. S. Rajendran entered the stage at the age of nine, and soon was acting in the dramatic troupes of the DK. It was Annadurai, in 1950, who had asked him to be in Parasakthi. ${ }^{25}$ In his career, S.S.R. has acted in some 85 films and, like M.G.R., plays the undaunted hero. During the late 1950s and early 1960s, S.S.R. was among the most popular stars of the Tamil screen. He worked tirelessly for the DMK in collecting funds, and in 1962, he was elected as a Member of the Legislative Assembly. His films glorified the party and were heavily laden with social reform. Indeed, he became known by the title Ilatchiya Nadigar, "Actor of Ideals."

At the height of his career, deepening personal problems brought S.S.R. into serious difficulty, both with the film industry and the party. Audience attendance began to fall off and producers, tired of his failure to show up for shootings and of his temper displays, no longer signed him for films. Having given most of his money to the party, S.S.R. now went deeply into debt. Within the party, he had long been opposed both by M.G.R. (with whom he vied for the same audience) and by Karunanidhi. Personal conflict with Karunanidhi now took on political color, and in 1967, in a bid to secure a DMK ticket for the Assembly, S.S.R. was passed over. Seeking to prove his party loyalty, he threw himself into the election campaign, and made a highly political film, Tangaratinam, timed for release during the campaign. The film, dealing with the love marriage of an untouchable girl and a high caste man, depicted a DMK conference and sought to appeal directly to the Harijan community.

During the campaign, S.S.R. announced that he had been threatened with murder, ${ }^{26}$ and before the election, his health broke in physical exhaustion. After the election, S.S.R. became outspokenly critical of the Karunanidhi

\footnotetext{
${ }^{28}$ See Hardgrave, The Dravidian Movement, op. cit., p. 75.

${ }^{24}$ Interview, Shivaji Ganesan, Madras, November 1969.

${ }^{25}$ Interview, S. S. Rajendran, Madras, December 1969.

${ }^{26}$ Dina Thanthi (Madras), January 16, 1967.
} 
group. His public statements, increasingly embarrassing to the party, finally culminated after Annadurai's death in the unofficial ostracism of S.S.R. from the DMK. S.S.R., convinced that people were trying to kill him, spoke of threats against his life. On one occasion, he reported an attack and beating to the police, but the case was dismissed when an investigation of the evidence suggested that the wounds were self-inflicted. Abandoned by his fans and his party, S.S.R. was sustained by his old friend, Shivaji, and dreamed of the comeback that would restore his stardom and his prominence in the DMK. But as both star and party stalwart, S.S.R. had been eclipsed by the DMK film luminary, M. G. Ramachandran.

M. Gopala Ramachandran ("M.G.R.") has been in Tamil films for 36 years, with star billing in more than 100 films since 1947, the year of his first important role. M.G.R. came to cinema from a stage career, beginning at the age of six, when he entered the Madurai Original Boys Company, where he learned acting, dancing, and sword-fighting-arts that served him well in his later career. ${ }^{27}$

Known as Vadiyar, ("teacher"), Puratche Nadigar, ("revolutionary actor"), and as Makkal Thilagam, ("idol of the masses"), M.G.R. is the symbol of hope for the poor in South India. He supports orphanages and schools and is always the first to give for disaster relief. After torrential rains in Madras, he gave raincoats to 6,000 rickshaw men. He is seen as "one among the people," "the incarnation of goodness," "the poor man's avatar." M.G.R.'s generosity is well advertised, for it is the grist of his fame. Every contribution to his philanthropic image is an investment in his continued popularity and following among the masses.

The rickshaw man is regarded as the archetype of the M.G.R. fan, the poor man of the laboring classes. For many, a substantial portion of their income goes for films, and to go on the opening day of a new M.G.R. film is the credential of real devotion-a willingness to pay a premium for a reserved seat or to wait from early morning to brave police lathis for a chance at general admission.

M.G.R. sees himself as the "protector" of the common man and is convinced of the moral purpose of his films. "My roles have been to show how a man should live and believe." ${ }^{28}$ With a purity and integrity reminiscent of the classic American western, the M.G.R. film is a morality play in which good inevitably triumphs over evil. The villain is the embodiment of evil, unrelieved in his darkness except in the love he holds for his beautiful daughter. The hero (M.G.R.) is all virtuous: He may be the captain of the guard in revolt against the tyrannies of a wicked dewan; a humble clerk at odds with a corrupt bureaucracy; a cowherder in struggle with a cruel landlord. Whatever the role, it is always the same: The audience expects and demands it. The hero neither smokes nor drinks, and is devoted to his

\footnotetext{
${ }^{27}$ See Hardgrave, "The Celluloid God: M.G.R. and the Tamil Film," South Asian Review, IV (July 1971), pp. 307-314.

${ }^{28}$ Interview, M. G. Ramachandran, Madras, December 1969.
} 
suffering mother. In love scenes with the villain's daughter, he is almost invariably the pursued rather than the pursuer. The fight scenes, wildly cheered by the fans, recall the swashbuckling Errol Flynn in a revised and "Bonded" version. The climax brings the defeat of villainy, uplift of the poor, and fulfilled romance in a "self-respect" marriage.

The films are filled with references which blur the role and the actor into one. Indeed, for the M.G.R. fan, the man is a projection of his screen image. In Enga Vittu Pillai ("The Son of our Home," 1965), M.G.R. sings, "If you follow me, the poor will never suffer. First Christ came and preached; then Gandhi came and preached; but the people have forgotten. Now I will set things right." In Nam Nadu ("Our Country," 1969), the hero is introduced in a series of short episodes: He helps an old woman walk across the street; captures a pickpocket; protects a young girl from "eve teasers"; and saves small children from eating unclean sweets. As the film progresses, there is a long queue waiting before a ration shop. A rich man arrives by car and is immediately supplied with his quota. M.G.R. intervenes and asks the man to stand in the line. Someone in the queue is heard to say, "If there is one like this man, then the country will be all right." Later, when our hero agrees to help some slum dwellers, one of them says, "Really you ,are a God."

For M.G.R., "Art and politics are the two sides of the same coin."29 The emblem of M.G.R.'s production company shows the DMK flag, and his films are filled with both direct and indirect references to the party. Early DMK films, like Parasakthi, were basically oriented to social reform, but as the 1957 elections neared, the party chose less obtrusive themes with more of a specifically political flavor. The demand for a separate state of Dravidasthan - then the cry of the DMK-would be couched in "folklore" films in which M.G.R. would struggle against an evil despot. Dialogue would obliquely refer to contemporary politics and gradually phrases were introduced to trigger applause-a reference to Anna or to the rising sun, symbol of the party.

In the folklore film Nadodi Mannan ("Vagabound King," 1958), there are numerous references in song and dialogue to "Dravida." In the film, an adaptation of The Prisoner of Zenda, M.G.R., crowned king, issues a decree that could easily pass for the DMK election manifesto. In Adimai Penn, the heroine points to the rising sun and tells M.G.R., "That is our god. Pray." Nam Nadu is perhaps the ultimate in this genre. A remake in color of an earlier Telegu success, the film exposes administrative corruption and social evil and is given a particular DMK flare. M.G.R. makes his first appearance wearing the party colors-a red shirt and black pants. He holds in his hands an open book with the pictures of both Gandhi and Annadurai on the cover. Throughout the film, the black and red combination appears, Annadurai's

\footnotetext{
${ }^{28}$ Quoted in Kalaichelvan (ed.), M. G. R. Ponmozhigal ("Golden Words of M.G.R.) (Madras: Tamil Nilayam, 1967), p. 13.
} 
portrait hangs on the wall of almost every scene, accompanied by pictures of Gandhi, and in one song, Anna is specifically called the "South Indian Gandhi." The huts of a slum fly the DMK flag. When M.G.R., the sacrificing government clerk turned politician in the cause of the poor, seeks election, his posters are in the red and black form of the DMK. M.G.R., in one scene, asks a slum dweller why grievances have not been brought to the Councillor. The poor man replies, "They say "Agattum Parkallam" "-a reference to the favorite phrase of Kamaraj, the Congress leader- "We will see." With M.G.R.'s election victory, a song proclaims, "The sun is rising, history is changing, and now everything will be alright." The film concludes with a self-respect marriage under a statue of Gandhi.

In January 1967, in an enactment of roles they had so often played together on the screen, M. G. Ramachandran was shot by M. R. Radha, a classical villain of the Tamil screen. Some have suggested that the shooting was politically inspired by Radha's devotion to the DK, but although this seems unlikely the events of that day remain confused in a background of both personal and political conflict. Within hours of the shooting, some 50,000 people had gathered at the hospital where M.G.R. had been taken. People were crying in the streets; shops closed. For six weeks, he lay in the hospital as fans awaited each report of his health. He was visited by the poorest people from the streets and by luminaries of Tamil film and politics. At the time of the shooting incident, M.G.R.'s popularity had been in gradual decline. The shooting, however, brought him to new heights of popularity. In a sense, it gave him new life. From his hospital bed, M.G.R. conducted his campaign for the Madras Legislative Assembly. The day before the election, the Madras newspapers carried an appeal from M.G.R. to the voters. With a large photograph of the actor in bandages, M.G.R. called upon the people of Tamilnadu to vote for the DMK. "I was to come to your homes, but it could not be done. Now I am asking for your hearts." ${ }^{30}$ In his constituency, he won twice the number of votes polled by his Congress rival and the largest vote polled by any candidate for the Assembly in Tamilnadu.

M.G.R.'s position in the DMK has long been controversial. Some people have argued that M.G.R. was responsible for the party's 1967 victory. He was at least a significant factor. Murasoli Maran, a DMK Member of Parliament and nephew of Chief Minister Karunanidhi, says that there is mutual reinforcement. ${ }^{31}$ Others, both within the party and out, negate any really significant role for M.G.R. in the party's advancement. Indeed, they believe

\footnotetext{
${ }^{30}$ Advertisement in Dina Thanthi (Madras), February 14, 1967. The Dina Thanthi is the most popular daily in Tamilnadu and has one of the highest circulations of any newspaper in India. Its publisher, S. B. Adityan, supported the DMK for the first time in 1967 and was made a minister in the new government. Before 1967, however, Adityan had been a strong opponent of the DMK - and particularly of M.G.R. At one time, the paper's policy was to refer to the actor as the "old hag" and to never carry his name or photograph.

${ }^{81}$ Interview, Murasoli Maran, Madras, November 1969.
} 
that his enormous popularity derives primarily from the party.

During the late 1940s, M.G.R. had known Annadurai. M.G.R.-then a Congressman - was reluctant to associate himself with the movement. In 1954, however, Karunanidhi had unsuccessfully tried to get Shivaji for a new film. He then turned to M.G.R., who had been moving toward the DMK politically. The film, Malai Kallan ("Dacoit of the Mountain"), was a great success, and overnight M.G.R. was a top star and soon joined the DMK. Shivaji had been a reluctant politician, and in M.G.R. the party found a willing image for mass appeal.

As M.G.R.'s popularity grew to rival that of the party itself, there were rumblings within the DMK against him. M.G.R. may have felt as well that he no longer needed the party and might benefit from official favor. In 1965 at a birthday celebration for Kamaraj, M.G.R. felicitated the Congress President as "my leader." Though M.G.R. later denied that he had said this, Karunanidhi, with whom he had had long personal conflict, sought to make an issue of it. In a huff, M.G.R. resigned as a Member of the Legislative Council. His seat in the upper house then went to a Congressman-infuriating many DMK members. At that time an M.G.R. film was running, and when the news came of his resignation, attendance began to drop off. People within the film industry and the party admit that this was basically a coincidence ("the film was a stinker and would have failed anyway"), but it was widely believed that he had feuded with party leaders and that DMK supporters were boycotting the film. His posters were slashed and defaced. It was at this time, amidst rumors that he was courting Congress, that M.G.R. gave raincoats to the rickshaw men, each emblazoned with the red and black symbol of the DMK. Today M.G.R. says his resignation was a "sacrifice" for the party, ${ }^{32}$ although just how remains unclear. Karunanidhi allegedly determined to finish M.G.R., allocated him a predominantly Congress constituency for the 1967 elections with the expectation that he would lose. He hadn't counted on M. R. Radha.

After the shooting and M.G.R.'s landslide election, his position within the party was considerably strengthened. He became party treasurer, and after the death of Annadurai in February 1969, Karunanidhi, now Chief Minister, faced up to a truce with the powerful actor in order to maintain party solidarity. The "honeymoon" was shortlived. By early 1972, M.G.R. and Karunanidhi were in open battle, with M.G.R.'s accusation of "dictatorship" and allegations of widespread corruption among ministers and party officials. In October, M.G.R. was suspended from the DMK.

M.G.R. is virtually indistinguishable from the party. "I am sacrificing my life for the sake of my politics."33 M.G.R. has been an important source of finance for the party, although now that the DMK is in power, it is less dependent on him. He has financed campaigns in a number of constituen-

a2Interview, M. G. Ramachandran, Madras, December 1969.

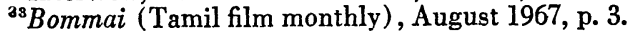


cies, but one DMK leader denies that he has made direct contributions to the party. "M.G.R. has publicity value," he says, and "helps collect money" for the DMK, but "not from his own pocket." Link magazine has described him as the "DMK's prop." ${ }^{34}$ His presence on the platform of party rallies and conferences has served as a drawing card for the masses. At the time of the 1968 World Tamil Conference, M.G.R. presented the city of Madras with a statue of Annadurai, erected at a busy intersection of Mount Road, the city's main thoroughfare. M.G.R.'s hundredth film was released in 1968 to coincide with Annadurai's birthday. His film, Adimai Penn ("Slave Girl,") released in 1969, just after the death of Annadurai, began with a view of Anna's statue.

Annadurai is once supposed to have said, "When we show his face, we get 40,000 votes; when he speaks a few words, we get 4 lakhs." M.G.R.'s fans are overwhelmingly DMK supporters, and some were surely drawn to the party by the star and co-opted as party workers. "I had no liking for any party," said one M.G.R. fan club member, but "since I like M.G.R., I began to support the DMK. When we worked for him in the 1967 elections, he used to give us the food which he himself would eat."

In a random survey on "film and society" in Tamilnadu, film star preference was significantly related to political party support. In the broadest terms, M.G.R. fans were DMK-inclined; Shivaji fans, Congress-inclined. In the urban sample, $81 \%$ of M.G.R. fans voted for the DMK in 1967, and only $16 \%$ for Congress. Of the Shivaji fans, $56 \%$ voted for Congress and $29 \%$ for the DMK. In the rural sample, the same pattern holds- $73 \%$ of M.G.R. fans voted for the DMK and only $19 \%$ for Congress. On the other hand, $71 \%$ of the Shivaji fans voted for Congress; $17 \%$ for the DMK. In examining the relationship between party vote and possible determinant variables, one variable, favorite star, accounted for $35 \%$ of the variation. In other words, whether an individual preferred Shivaji or M.G.R. was the best predictor of how he voted in the two elections-Shivaji fans for Congress; M.G.R. fans for the DMK.

The relationship between star preference and party vote is confirmed in looking at these same data from the party perspective. Of Congress voters in 1962, 73\% favored Shivaji; 16\%, M.G.R. The star's party identification seemed even more clearly evident in 1967. The Shivaji preference rose to $76 \%$, and M.G.R. declined to $13 \%$. In terms of DMK voter preference, $39 \%$ of those voting for the party in 1962 liked Shivaji; 61\%, M.G.R. With considerably greater numbers in 1967 , DMK voters indicated a preference for Shivaji of $42 \%$, as against $58 \%$ for M.G.R. This might appear, at first glance, to suggest that M.G.R. was losing his hold over the DMK voter, but with the increase of some $14 \%$ in popular vote from 1962, it is clear that the party had been able to attract new support from the Shivaji

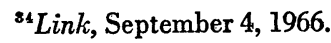


audience. In addition, a significantly larger portion of the M.G.R. audience voted for the DMK in $1967 .^{35}$

The identification of the film star and party are reflected in the popular images of the stars. The relics and accouterments of fandom are omnipresent in Tamilnadu and are often infused with political symbolism. Multicolored lithographs present dream images of the stars: M.G.R. against the embattled banner of the DMK; M.G.R. in spacesuit with DMK armpatch, as the first man on the sun; Shivaji, bleeding, as a Congress freedom fighter in the struggle for independence; Shivaji in conference with Kamaraj over the fate of the nation.

Both M.G.R. and Shivaji pay considerable attention to their fans, and fan clubs (rasigar manrams) have been organized to advance the image of the stars. Shivaji claims three thousand fan clubs in Tamilnadu, and among their various functions, political activity for the Congress looms high. Some of the clubs are directly associated, even coterminous, with Congress organizations. The letterhead stationery of various clubs are printed in the orange, green, and white colors of the Congress and depict the Congress flag. The party flag flies from the office buildings, and Shivaji's pictures share the walls with those of Congress leaders. During the elections, the clubs organize public meetings, often with Shivaji's presence, and make personal contacts to secure votes for Congress. The activities of the manrams form an important part of the Congress electoral effort in Tamilnadu, and the fans have been dedicated political workers. In 1970, a massive all-India Shivaji Manram conference was held in Madras. With Kamaraj in attendance, Shivaji made an emotional pledge to live and die for Kamaraj. ${ }^{36}$

There are some four to five thousand fan clubs claimed for M.G.R. in South India. Loosely organized, in contrast to the Shivaji clubs, an M.G.R. fan club would seem to form whenever three or four fans come together. Their devotion to the star, however, is all-absorbing, and the fan is likely to subordinate all other activities to the manram. Like those of Shivaji, the fan clubs are politically involved, although apparently with little central direction. The clubs officially have no politics, but most operate as loose adjuncts of the DMK and have been deeply involved in electoral campaigns.

The 1967 elections brought film stars into the political arena for both Congress and the DMK. The Congress sought to follow the DMK in the use of propaganda in film, and Gemini Studios produced one specifically political film for the Congress party, Vazhaga Nam Thayagam ("Long Live Our Motherland"), starring Shivaji Ganesan and the popular comedian Nagesh. Shivaji and the actress Padmini worked tirelessly for Congress throughout the "star-studded" campaign. Congress, however, was late in

\footnotetext{
${ }^{85}$ For a detailed examination of the survey, see Hardgrave, "Film and Political Consciousness in Tamilnadu," paper presented at the annual meeting of the American Political Science Association, Washington, D.C., 1972. Also see Hardgrave, "Film and Society in Tamil Nadu: A Profile," Monthly Public Opinion Surveys of the Indian Institute of Public Opinion, New Delhi, XV, (March, April, 1970), pp. 1-62.

${ }^{\circ} \mathrm{N}$. S. Jagannathan in The Hindustan Times, February 12, 1971.
} 
the act. The DMK had used the film and film stars as a vehicle for propaganda and political mobilization since the party's inception. The cinema was a vital element in the landslide victory that brought the DMK to power in 1967. ${ }^{37}$ After the DMK's electoral victory, the southern correspondent for Filmfare, India's premier film magazine, wrote, "The DMK . . . rose to prominence and secured its vast popularity mainly through its script writers." 38 Two years later, Filmfare reiterated that the Tamil film industry's "whole-hearted participation and complete identification with the DMK party in general and Anna in particular was responsible for the mass support the party received and with which it ultimately captured power in Tamilnad."39

In power, the party consolidated its position with the film industry. The president of the South Indian Film Chamber of Commerce was appointed by Annadurai to the honorific position of Sheriff of Madras. Congress producers and film directors now sought to cash in on the popularity of the DMK, with the introduction of DMK symbols and references into their films. The new government gave emphasis to the film division of the state's information department. New documentaries, shown weekly throughout Tamilnadu, depicted party leaders at every opportunity.

The 1971 assembly elections in Tamilnadu again brought out the stars. Annadurai was dead, but Karunanidhi was in full command of the DMK. For three weeks, the studios of Kodambakkam - "the Hollywood of Madras" -were silent. In the words of Link magazine, "The entire star billing was on deputation to politics"-and most had been mobilized by the DMK. M.G.R., defending the record of the DMK in office, addressed more than 1400 party rallies. Shivaji, for the Organization Congress, addressed some 2000 public meetings throughout the state. ${ }^{40}$ The DMK held its own, and the party of Tamil nationalism was again returned to power.

The films of the DMK today are unlikely to shock or pose a serious challenge to traditional values. The early plays and films of the Dravidian Movement indeed had been revolutionary in content, but since the mid-1950s, the themes of social reform have been diluted in electoral compromise. Today, DMK films are less a catalyst to reform and revolution than a catharsis of counter-revolutionary tension release. Situations of structural conflict (landlord v. landless laborer; capitalist v. factory worker) are mediated through romantic love. Sex becomes a social solvent. Villainy is defeated-and perhaps, like M.G.R., the poor rickshaw man will be able to marry the rich man's daughter. "The revolutionary urges of the masses," writes Mythily Shivaraman in Mainstream, "find a vicarious fulfillment in the movies while in reality they are denied a real-life forum for articulation.

\footnotetext{
${ }^{87}$ For an analysis of the 1967 election, see S. K. S. Nathan, "The DMK and the Politice of Tamilnad," Economic and Political Weekly, December 19, 1967, pp. 2133-40.

${ }^{38}$ Filmfare, May 12, 1967.

${ }^{30}$ Filmfare, February 28, 1969.

${ }^{\star 0}$ Link, March 14, 1971.
} 
The close identification between the movies and the party . . . creates the happy illusion among the people that the Government is on 'their side." "41

Even in catharsis, however, the DMK's use of film represents one of the few self-conscious efforts to employ the medium for political purposes. In propaganda and mobilization, the film has played a significant role in the rise of the DMK, and, for good or ill, the stars have influenced the fate of Tamil society.

${ }^{41}$ Mythily Shivaraman, "DMK: Kisan's Friend or Foe? Mainstream, August 30, 1969, p. 29.

ROBERT L. HARDGRAVE, JR., is an Associate Professor of Government at the University of Texas, Austin. 